\title{
University Students' Attitudes toward Natural Birth
}

\author{
Handan $\mathbf{0}^{1 *}$ and Gulay $\mathbf{R}^{2}$ \\ ${ }^{1}$ Department of Womens Health and Diseases Nursing, Gumushane University, Turkey \\ ${ }^{2}$ Department of Womens Health and Diseases Nursing, Istanbul University, Turkey
}

Submission: November 07, 2017 ; Published: November 28, 2017

*Corresponding author: Handan 0, Department of Womens Health and Diseases Nursing, Gumushane University, Turkey, Tel: +904562337637; Fax: +904562337427; Email: hndnozcn@hotmail.com

\begin{abstract}
Introduction: Today, where awareness toward natural birth frequently finds a voice and it's been increasingly questioned, views of young people on natural birth, who are one step closer to become parents' is of importance. The study was planned in this perspective, to assess views of students of Gumushane University on natural childbirth.
\end{abstract}

Methods: After getting required consent, 641 participants who volunteered were interviewed face-to-face and the questionnaire was filled. Students who have attended the study were randomly picked from each department.

Results: Age of participants varied between 18 and 38 and the median age was determined to be $20.84 \pm 1.97$. A 61.3 percent of participants were women and 97.2 were single. A 32.9 percent of the participants declared fear of labor pain, 20.2 feared delivering a disabled or sick child and 17.9 percent had fear of perineovaginal fracture. A 35.0\% majority of participants said that they would prefer normal birth as they see it more suitable to baby's health while another $11.8 \%$ expressed they would favor cesarean, as it offered less pain. A total of $78.7 \%$ of the participants said that they find it important to have childbirth preparation classes during labor.

Conclusion: Nowadays, due to the increased rate of cesarean section and invasive delivery preferences, raising awareness regarding natural birth among a new generation of young people in our society is of important concern and we feel the need to emphasize the importance of developing and supporting educative and informative programmes for this people.

Keywords: Natural labor; Students; Informative; Fear

Abbreviations: TNSA: Turkey 2003 Demographic and Health Survey

\section{Introduction}

Labor is a natural, normal and healthy human experience [1]. Natural birth is defined as the act of giving birth; one in which no outside intervention takes place and the woman is actively involved, guided by her instincts [2]. In parallel with natural birth, we are often introduced with the concept of active birth. Although active birth is an approach that emphasizes the importance of the concept of natural birth and grants women the freedom of movement during labor; in line with their instincts, it is not yet widespread in our country [2,3]. However, the analysis of recommendations on natural childbirth reveals similarities to labor-related studies with a high level of evidence and recommendations from other evidence-based guidelines $[4,5]$. In the last thirty years, invasive procedures that utilize high technology in order to protect the health of the mother and her baby has gained roots in deciding on the birthing act. This is defined as the active management of labor and is very important as the expression itself refers to the activeness; not of the woman who performs the act of birth, but of people who possess tremendous knowledge and technological equipment [6]. In our hearts of course, the birthing act should be welldefined on the mother and the baby's side. It is everybody's desire for the women to be able to enjoy this rare, magical and exciting moment of their lives and moreover, participate in this unique act.

The less intervention there is in this miraculous moment, more easy it would become for the mother and the baby to healthily progress through the steps of this journey [2]. Yet, unforeseen problems may be encountered during this trip. About 85 to 90 percent of women can deliver normally, while a $10 \%$ need help completing this journey $[1,2]$. There is no such approach that justifies the thought: Every woman should prefer a natural birth. Every moment of labor is full of unknowns; 
deviations from the norm may be experienced at any minute. Correct intervention by the health care team in these very moments may save lives. Implemented procedures by the health care team who possesses the necessary knowledge, equipment and experience, helps mothers and their babies that are stuck up on any point through this journey. Furthermore, it is very important for health workers to interfere as less as possible and just when it is absolutely needed [2].

Cesarean is one of the more sophisticated forms of surgery until the day. After all, the mother's and baby's health is in question. Caesarean section at the right time and with real reasons behind may save the lives of the mother and her baby. So, it is a rescue intervention. With achievements made during the last 40 years in regards to anesthesia and surgery, cesarean has become one of the most reliable forms of medical intervention. Where in the beginning, it was only applied for in moments of need, when we look at today, we most possibly encounter arbitrary applications. Cesarean section, in our country, is one of the most commonly performed surgical operations [2]. Latest indicators of birth have reached $40 \%$ at times, whereas in Turkey 2003 Demographic and Health Survey (TNSA), rate of caesarean was about 21.2 percent. This rate is $5-15 \%$ above the target set by the World Health Organization [7].

Although non-independent by region, a study by Pala and Avci found the cesarean delivery rate to be $85.7 \%$ in private hospitals [8]. Natural birthing is a method in which there is as much possible interference. All unnecessary interference would negatively affect the functioning of labor and the secretion of hormones. Labor and childbirth is a physiological condition and never a disease [9]. Since the 19th century, births have moved from home into hospital environments; it is easily forgotten that labor is a normal, physiological process and even more, the belief that it created a potential risk for the women and her baby have raised [1]. Today, where awareness toward natural birth frequently finds a voice and it's been increasingly questioned, views of young people on natural birth, who are one step closer to become parents' is of importance. The study was planned in this perspective, to assess views of students of Gumuhane University on natural childbirth.

\section{Materials and Methods}

This definitive study was intended to assess Gumushane University students' attitudes toward natural birth. The data in question was designed to assess knowledge on act of birth giving by use of a socio-demographic fact sheet. After getting required consent, 641 participants who volunteered were interviewed face-to-face and the questionnaire was filled. Students who have attended the study were randomly picked from each department, that is; Mechanical Engineering, Civil Engineering, Business Management, Economics, Communication, Public Administration, Theology, Accounting, Nutrition, Nursing, Disaster Emergency, First Aid, Medical Laboratory, Electric and Food Engineering. Also, in order to allow for a comparison between medical student who receive birthing classes and the rest of students, questionnaires were prepared for Nursing 3rd and 4 th grades and First Aid 1st and 2nd grades. Students were given a brief about natural birth and invasive birth, beforehand. Tha data was analysed through use of SPSS for Windows, version 15.0 bundle software and ki square test.

\section{Results}

Table 1: Distribution of participants fears towards birthing act.

\begin{tabular}{|c|c|c|}
\hline Fear Towards Labor & $\mathbf{n}$ & $\mathbf{\%}$ \\
\hline No Fear & 148 & 23.1 \\
\hline Fear of Labor Pain & 211 & 32.9 \\
\hline Fear of Dying at Birth & 76 & 11.8 \\
\hline Fear of Delivering a Disabled/Sick Child & 130 & 20.2 \\
\hline Fear of Perineovaginal Fracture & 115 & 17.9 \\
\hline Other Fears & 76 & 11.8 \\
\hline
\end{tabular}

Age of participants varied between 18 and 38 and the median age was determined to be $20.84 \pm 1.97$. A 61.3 percent of participants were women and 97.2 were single. Distribution in year from 1st to 4th grade has been 37.5, 37.7, 19.6 and 5.2, respectively (Table 1). In a general look, the longest time of life spent in percent was 15.9 in villages, 35.2 in districts and 48.9 in cities. Income wise; 25.2 percent stated their income as being lower than their spendings, $59.6 \%$ stated these as being in balance and 15.2 stated their income to be higher then their spendings. Upon a background check for having received previous training or tution on natural birth; 69.6 was found to have received none (79.4 percent of students except those who have received birth classes and study in other branches); those who have received tution have pointed out to their sources as Friends (18.25\%), Newspapers (32.6\%), Internet (20.9\%) and medical team (6.4\%). When questioned about from where they would like to receive information regarding birth, $24.8 \%$ have named midwife, $4.5 \%$ nurse, $70.7 \%$ doctor and $6.4 \%$ named other medical personel (Table 2).

Table 2: Distribution of Thoughts on a Healthy Delivery Method for Mother and Child.

\begin{tabular}{|c|c|c|}
\hline Delivery Method & $\mathbf{n}$ & $\mathbf{\%}$ \\
\hline Natural and Non-Invasive Delivery & 148 & 24.4 \\
\hline Normal Delivery with Invasion When Needed & 323 & 53.3 \\
\hline $\begin{array}{c}\text { Normal Delivery with Surgical Intervention and } \\
\text { Invasions }\end{array}$ & 124 & 20.5 \\
\hline Cesarean Delivery & 11 & 1.8 \\
\hline
\end{tabular}

Participants were asked to specify their method of choice with which they've given birth and the findings were as follows: 29.1\% home birth, 35.7\% hospital, 25.6\% through intervention in a hospital and $9.6 \%$ through caesarean section. Statistically significant differences between gender type on determining what is healthy in terms of delivery method for women and their babies were discovered. Men are more likely than women, to approve natural and non-invasive delivery (38.7\%), where women find it more appropriate to have an invasive delivery. 


\section{Journal of Gynecology and Women's Health}

Men more strongly feel that natural delivery is healthier for mother and her baby (Table 3 ).

Table 3: A genderly comparison of views on delivery method, in regards to the status of women and their babies health.

\begin{tabular}{|c|c|c|c|c|}
\hline \multirow{2}{*}{ Delivery Method } & \multicolumn{2}{|c|}{ Women } & \multicolumn{2}{c|}{ Men } \\
\cline { 2 - 5 } & $\mathbf{n}$ & $\mathbf{\%}$ & $\mathbf{n}$ & $\mathbf{\%}$ \\
\hline Normal and Non-Invasive Delivery & 57 & 15.4 & 91 & 38.7 \\
\hline $\begin{array}{c}\text { Normal Delivery with Invasion } \\
\text { When Needed }\end{array}$ & 209 & 56.5 & 113 & 48.1 \\
\hline $\begin{array}{c}\text { Normal Delivery with Medical } \\
\text { Intervention and Invasions }\end{array}$ & 94 & 25.4 & 30 & 12.8 \\
\hline Cesarean Delivery & 10 & 2.7 & 1 & 0.4 \\
\hline Total & 370 & 100 & 235 & 100 \\
\hline
\end{tabular}

Table 4: A comparison of genderwiththequestion: Whatwould be yourprefferredmethod of delivery, ifitwererequired?.

\begin{tabular}{|c|c|c|c|c|}
\hline \multirow{2}{*}{ Delivery Method } & \multicolumn{2}{|c|}{ Women } & \multicolumn{2}{c|}{ Men } \\
\cline { 2 - 5 } & $\mathbf{n}$ & $\mathbf{\%}$ & $\mathbf{n}$ & $\mathbf{\%}$ \\
\hline Cesarean Delivery & 24 & 6.6 & 6 & 2.9 \\
\hline Normal Birth & 222 & 61 & 112 & 54.9 \\
\hline Normal Birth with Invasion & 95 & 26 & 43 & 21.1 \\
\hline I don't know & 25 & 6.8 & 43 & 21.1 \\
\hline Total & 370 & 100 & 235 & 100 \\
\hline
\end{tabular}

Table 5: Participants reasoningsfortheirpreferredmethod of delivery.

\begin{tabular}{|c|c|c|}
\hline For Normal Birth & n & $\mathbf{\%}$ \\
\hline More suitable for my baby & 224 & 35 \\
\hline Less pain in postpartum & 76 & 11.8 \\
\hline It's the natural thing to do & 160 & 24.9 \\
\hline Can return to normal life more easily & 190 & 29.6 \\
\hline Discharged from hospital in less time & 31 & 4.8 \\
\hline
\end{tabular}

Table 6: Participants views on labor.

\begin{tabular}{|c|c|c|c|}
\hline Opinions & I Agree (\%) & I Don't Agree (\%) & $\begin{array}{l}\text { Undecided/No Idea } \\
(\%)\end{array}$ \\
\hline Labor is a normal, physiological act & 93 & 1.7 & 5.2 \\
\hline Is an instinctive act on & 53.2 & 21.8 & 25 \\
\hline Approximately $80 \%$ of women can naturally give birth & 72.7 & 7.9 & 19.4 \\
\hline Woman and her baby are at potential risk in delivery & 65.5 & 15.9 & 18.7 \\
\hline Women in labor must be active (able to move freely). & 57.5 & 17.9 & 24.6 \\
\hline Health care team should regulate the act and women should remain passive. & 38.8 & 38.2 & 23 \\
\hline $\begin{array}{c}\text { Every woman has a right to decide on the environment, and in choosing of } \\
\text { interventions. }\end{array}$ & 81 & 10.3 & 8.7 \\
\hline $\begin{array}{c}\text { The baby should be kept in her mothers lap for } 5 \text { to } 10 \text { minutes, following } \\
\text { delivery }\end{array}$ & 54.6 & 14.9 & 30.5 \\
\hline Cesarean is a rescue surgery & 53 & 23.1 & 24 \\
\hline Women with fear of childbirth can make delivery by caesarean section. & 41.4 & 38.6 & 20 \\
\hline Normal vaginal birth after cesarean is possible & 21.1 & 31.9 & 47 \\
\hline Births should take act in well-equipped hospitals & 87 & 7.1 & 5.9 \\
\hline
\end{tabular}

\begin{tabular}{|c|c|c|}
\hline Other & 35 & 5.5 \\
\hline For Cesarean Delivery & $\mathbf{n}$ & $\mathbf{\%}$ \\
\hline Less pain & 76 & 11.8 \\
\hline Baby is much safer & 60 & 9.3 \\
\hline Lessfractureduringdelivery & 42 & 6.5 \\
\hline Delivery is done in less time & 60 & 9.3 \\
\hline Easiertomanageforthehealthteam & 62 & 9.7 \\
\hline Other & 80 & 12.5 \\
\hline
\end{tabular}

A statistically meaningful difference between genders on determining "what would be your preferred method of delivery?" was discovered. When percentage distribution is taken into consideration, it can be seen that normal birth is highly rated. A $35.0 \%$ majority of participants said that they would prefer normal birth as they see it more suitable to baby's health while another $11.8 \%$ expressed they would favor cesarean, as it offered less pain (Table 4). A total of $78.7 \%$ of the participants said that they find it important to have childbirth preparation classes during labor. Almost all of the participants (93.0\%) are aware of the physiological process of labor. Again, the vast majority of respondents $(81 \%)$ responded that every woman has the right to vote and decide on the environment and the interventions (Table 5). Women after cesarean delivery; $21.1 \%$ of those said that normal vaginal delivery is possible and $41.4 \%$ who have fear of labor said that they would have a caesarean section. Students who took preparation classes and students from any branch but health, did not differ significantly $(X 2=4.361, p=.225)$. Students of health who took prep classes and others outside the field also did not differ significantly regarding women's and baby's health in terms of delivery (X2=6.667, $\mathrm{p}=.083$ ) (Table 6). 


\section{Discussion}

The choice of delivery method is an important decision for the health of both mother and baby. It's been determined with many studies that the majority of women prefer natural birth as a form of delivery [10-12]. In the mentioned study, $58.7 \%$ of university students has preferred normal birth over a $24.7 \%$ who has voted in favor of invasive birth. Similar to the results from other studies, our study findings confirmed that the preferred method of delivery is majorly normal delivery, among students. It is indeed very pleasing to know that today, although the cesarean section rate is on the rise, new generation sides itself with normal birth.

In the studies, reasons for choosing normal vaginal delivery has been listed as such; it being natural, postpartum period being less painful and quicker to recover, being cheaper, being more secure and a bettered method of delivery $[11,12]$. In Doğaner et al. [13] study, students who choose normal birth (88.5\%) 60.3\% indicated that they prefer normal birth as it is more natural. In another study by Chong et al. [14] it's been concluded that a $24 \%$ of women who preferred natural birth would do so for it is natural and physiologically normal. In our study, young people have been discovered to favor normal delivery as they find it; more suitable for the baby's health (35\%), more comfortable to return to normal life $(29.6 \%)$ and more of a natural process (24.9\%). Similar to the results of other studies on this topic, in our study findings; the theme neutrality standed out among reasonings behind normal delivery.

More recently, studies on patients with prior cesarean section revealed that a 60 to 80 percent of these were reported to make successful vaginal delivery if they were given a chance [15]. Repeated rate of cesarean delivery has been $35 \%$ in Australia [16]. In this study; "is normal vaginal birth after cesarean delivery possible?" knowledge had been questioned. While $47 \%$ of respondents declared to have no idea, a 31,9\% stated that it cannot be done. We believe that; for the young people to remain undecided on this issue or have a negative idea, the issue of vaginal birth after cesarean may still be very new and insecurities due to lack of knowledge may be in effect. Therefore, it is expressed that; once evidence-based disclosure of risks and benefits of caesarean section and vaginal delivery are made public and especially women who have given birth by caesarean section are encouraged towards vaginal birth [17] it may be possible to reduce caesarean rates.

Labor pain is one of the important factors that may affect individuals' preference for method of delivery. Among pregnant women, a 5 to 20 percent had fear of childbirth [18]. The study which have been realized with 2206 women discovered this fear to be related to the duration of delivery by 90.6 percent [19]. In this study, 32.9 percent of students said they feared delivery pain. Similar to our findings, in a study with the students; $53.2 \%$ stated that they prefer caesarean section as the idea of normal delivery would be too painful for them [13]. In today's world, labor is still seen as a very painful and dangerous process, thereby driving women towards having cesarean [2]. It is possible to say that the outlook towards labor pain would be positively affected, once struggle with labor pain gives way to uniting with it and the new generation is confident with this unity and towards labor pain.

Pregnancy is a very special case and one of the most beautiful life experiences for mothers and fathers to become. However, word of mouth on negative experiences may take their places among birth stories that are being told for many years. The spread of this kind of sharing of experiences among women, also the painful scenes related to birth in visual media causes women to constitute a false image of labor [2,9]. Cultural norms, family relationships and clinical risks affect decision of women regarding method of delivery. It is important for support organizations to promote and inform women towards natural childbirth [20].

In our study, $69.6 \%$ of students have said that they did not receive any training on delivery and among the $21.7 \%$ who have received training reported to have done so from a health team. Upon assessing students who study in branches other than health and those who did not receive classes, the rate for having received no prior education has been 79.4 percent. This shows us that young people's lack of knowledge on the act of birth, especially for students studying outside the health field, this ratio seems to be quite high. In our study, fostering of a positive point of view towards natural birth for young people is of special concern; as it is important in the determination of preferences on the method of birth.

\section{Conclusion}

It is thought-provoking that although almost all of the students agree on labor being a normal process, only half of them stated that they would prefer normal birth. Thinking that among them, only $21.1 \%$ had knowledge of "normal vaginal birth being possible after cesarean delivery" shows that there's a lack of knowledge regarding this matter. Among the participants, $32.9 \%$ have said that their fear of birth was caused by fear of labor pain. Nowadays, due to the increased rate of cesarean section and invasive delivery preferences, raising awareness regarding natural birth among a new generation of young people in our society is of important concern and we feel the need to emphasize the importance of developing and supporting educative and informative programmes for this people.

\section{Acknowledgement}

We thank all of the women who participant of research and share their personal experiences. We would also like to thank Gumushane University where allowing the construction of the work.

\section{References}

1. Mongan MF (2005) Hypnobirthing the mongan method. (3 $3^{\text {rd }}$ edn), Health Communication, Inc. Deerfield Beach, Florida, USA. 
2. Rathfisch G (2012) Doğal Doğum Felsefesi. Nobel Tip Kitapevi, Istanbul, Turkey.

3. Balaskas J (2007) Preparing for active birth handbook. Essential information for making empowered choices. Active Birth Center, UK.

4. NICE The National Institute for Health and Clinical Excellence (2007) Intrapartum Care of Healthy Women and their babies.

5. Department of Veteran Affairs, Department of Defense (VA/DoD) (2009) VA/DoD Clinical Practice Guideline for Management of Pregnancy.

6. Dick RG, Michel O (2010) Childbirth Without Fear. Pinter \& Martin, UK.

7. TNSA Türkiye Nüfus ve Sağhk Araştirmasi (2008) Hacettepe Üniversitesi Nüfus Etütleri Enstitüsü.

8. Avci K, Pala K (2005) Bursa il Merkezindeki Hastanelerde Doğum Yapan Kadınlarda Sezaryen Doğum Oranları ve Bunu Etkileyen Bazi Etmenlerin incelenmesi. Halk Sağhği Günleri, Ankara.

9. Sayiner D, Özerdoğan N (2009) Doğal Doğum. Maltepe Üniversitesi Hemşirelik Bilimve Sanati Dergisi 2(3):142-146.

10. Hopkins K (2000) Are Brazilian Women really choosing to delivery by cesarean? Soc Sci Med 99(4): 557-580.

11. Aslam MF, Gilmour KR, Fawdry DS (2003) Who wants a caesarean section? A study of woman's personel experience of vaginal and caesarean delivery. J Obstet Gynaecol 23(4): 364-366.

12. Lee S, Khang Y, Lee M (2004) Women's attitudes toward mode of delivery in South Korea-a society with high cesarean section rates. Birth 31(2): 108-116.
13. Doğaner G, Doğaner A, Duran Ö, Tuna M, Tezcan \$̧, et al. (2013) Sağhk Bilimlerinde Okuyan Öğrencilerin Doğum Şekli Tercihlerine Yönelik Düşüncelerinin Belirlenmesi. Türk Jinekoloji ve Obstetrik Derneği Dergisi 10(1): 31-36.

14. Chong ES, Mongelli M (2003) Attitutes of Singapore Women toward cesarean and vaginal deliveris. Int J Gynaecol Obstet 80(2): 189-194.

15. Chauhan SP, Martin JN, Henrichs CE, Morrison JC, Magann EF (2003) Maternal and perinatal complications with uterine rupture in 142.075 patients who attempted vaginal birth after cesarean delivery: a review of the literature. Am J Obstet Gynecol 189(2): 408-420.

16. McGrath P, Ray-Barruel G (2009) The easy option? Australian findings on mothers' perception of elective Caesarean as a birth choice after a prior Caesarean section. Int J Nurs Pract 15(4): 271-279.

17. Yilmaz M, Isaoğlu Ü, Kadanah S (2009) Kliniğimizde 2002-2007 yillari arasında sezaryen olan hastaların incelenmesi. Marmara Medical Journal 22(2):104-110.

18. Rouhe H, Salmela-Aro K, Halmesmaki E, Saisto T (2009) Fear of childbirth according to parity, gestational age, and obstetric history. BJOG 116(1): 67-73.

19. Adams S, Eberhard-Gran M, Eskild A (2012) Fear of childbirth and duration of labour: a study of 2206 women with intended vaginal delivery. BJOG 119(10): 1238-1246.

20. Frost J, Shaw A, Montgomery A, Murphy D (2009) Women's views on the use of decision aids for decision making about the method of delivery following a previous caesarean section: qualitative interview study. BJOG 116(7): 896-905.
Your next submission with Juniper Publishers will reach you the below assets

- Quality Editorial service

- Swift Peer Review

- Reprints availability

- E-prints Service

- Manuscript Podcast for convenient understanding

- Global attainment for your research

- Manuscript accessibility in different formats

(Pdf, E-pub, Full Text, Audio)

- Unceasing customer service

Track the below URL for one-step submission https://juniperpublishers.com/online-submission.php 